\title{
Job Insecurity and the Timing of Parenthood: A Comparison between Eastern and Western Germany
}

\section{Perceptions de l'instabilité de l'emploi et projet d'enfant: Une comparaison entre Allemagne de l'est et allemagne de l'ouest}

\author{
Laura Bernardi · Andreas Klärner • \\ Holger von der Lippe
}

Received: 21 November 2006/Accepted: 19 July 2007/Published online: 21 November 2007

(C) Springer Science+Business Media B.V. 2007

\begin{abstract}
This article contributes to the ongoing debate on the economic determinants of fertility behavior by addressing the role of job insecurity in couples' intentions concerning parenthood and its timing. It starts from the hypothesis that cultural values moderate individuals' reactions to job insecurity and the way it is related to family formation. With a systematic thematic content analysis of a set of semi-structured interviews with childless men and women around the age of 30 in eastern and western Germany, we are able to show that there are substantial differences in the consequences of job insecurity on intentions to have a first child. In western Germany, a relatively secure job career is expected to precede family formation, and this sequence of transitions is rather rigid, whereas in eastern Germany job security and family formation are thought of and practiced as parallel investments. We suggest that the lack of convergence in family formation patterns between eastern and western Germany after the unification of the country in 1990 is partially related to different attitudes toward job insecurity in the two contexts.
\end{abstract}

Keywords Family formation · Fertility - Germany · Job insecurity · Qualitative interviews · Social change

Résumé Cet article contribue au débat en cours sur les déterminants économiques du comportement de fécondité, en questionnant le rôle de l'insécurité de l'emploi par rapport au projet d'enfant et à son calendrier. L'hypothèse posée est que les valeurs culturelles conditionnent en partie les réactions à l'insécurité de l'emploi et le lien aux processus de formation des familles. Par une analyse systématique des

L. Bernardi $(\bowtie) \cdot$ A. Klärner · H. von der Lippe

Max Planck Institute for Demographic Research, Konrad-Zuse-Str. 1, 18057 Rostock, Germany

e-mail: bernardi@demogr.mpg.de

URL: http://user.demogr.mpg.de/bernardi 
thèmes contenus dans un ensemble d'entretiens semi-directifs conduits auprès de personnes sans enfants âgées d'environ 30 ans en Allemagne de l'est et en Allemagne de l'ouest, nous avons démontré l'existence de réelles différences dans les répercussions de l'insécurité de l'emploi sur les projets de premier enfant. En Allemagne de l'ouest, un emploi stable doit obligatoirement précéder la venue d'un enfant, et la séquence est relativement rigide, alors qu'en Allemagne de l'est, l'obtention d'un emploi stable et la formation d'une famille sont conçus comme des investissements parallèles. Notre suggestion est que le manque de convergence dans les schémas de formation des familles entre les deux parties de l'Allemagne après l'unification du pays en 1990 pourrait être liée, au moins en partie, à des différences d'attitudes par rapport à l'insécurité de l'emploi.

Mots-clés Formation des familles · Fécondité · Allemagne ·

Insécurité de l'emploi · Entretiens qualitatifs · Changement social

\section{Introduction}

There are two noticeable aspects to the evolution of fertility patterns in eastern Germany following the unification of the country in 1990. The first is the very wellknown drop in fertility rates to levels below those of the old federal states (from 1.6 in 1989 to 0.8 in 1994; Adler 1997, p. 41); this steep drop of fertility is a characteristic pattern observed in almost all eastern European countries after the fall of the socialist regimes, and has been attributed to the rapid social and economic changes, the economic crisis, and the unprecedented high levels of unemployment ${ }^{1}$ (Sobotka 2004). In this context, the rapid decline in eastern German birth rates is not surprizing. The second noticeable aspect of fertility development in the region is puzzling: Eastern Germans continue to become parents more often and do so at younger ages than their western counterparts. The relatively early parenthood of eastern Germans is particularly puzzling since micro data show that it is also true for individuals who face higher socio-economic insecurity and unemployment. Women even face higher risks of having children when they are unemployed (Konietzka and Kreyenfeld 2004).

Therefore, the interesting question is not why fertility is so low in eastern Germany, but why eastern Germans become parents earlier than their western counterparts despite facing worse labor market conditions. This question has a universal value since it calls for a thorough examination of how job insecurity is related to family formation.

The concept of job insecurity has been discussed at length in relevant literature: while there is evidence that job insecurity is related to job instability and employment precariousness (Elman and O'Rand 2002; Ahn and Mira 2002), there is general agreement that job insecurity is a multidimensional concept which refers

\footnotetext{
1 In eastern Germany, the recorded level of unemployment was $18.8 \%$ in 2005 (Statistisches Bundesamt 2005).
} 
mainly to the subjective perception of being at risk of losing one's own job or some of its features, or more restrictively, the perceived stability and continuance of one's employment with an organization (Hartley et al. 1991; Klandermans and van Vuuren 1999; Sverke and Hellgren 2002; Sverke et al. 2002; 2006; Green 2003). Researchers studying the psychological consequences of job insecurity have focused on the quality of work, the workers' health, wages, or the patterns of leaving home (Barling and Kelloway 1996; Probst and Brubaker 2001; Kausto et al. 2005; Becker et al. 2005; Anderson and Pontusson 2007; Green 2007). Despite the significant interrelation between fertility behavior and the two related factors of labor force participation and employment status (Engelhardt et al. 2004; Engelhardt and Prskawetz 2004), virtually no empirical research focuses on whether the perceived job insecurity affects fertility intentions and behavior. The relationship between the subjective definition of one's own employment perspective and fertility intentions are a fascinating area of research; they open a window on the way in which objective conditions are mediated by the subjective interpretations of them. It has been argued and shown that job expectations, feelings of security and stability, perceptions of job insecurity, and reactions to these feelings are all mediated by cultural values acquired through socialization (Hui 1990; Schwartz 1990; Probst and Lawler 2006). This is consistent with the cognitive anthropological wisdom predicting that all sorts of information are processed through cultural schemas (D'Andrade 1997) which influence the aspects of reality that are noticed, and salient to the individual and the way in which they are evaluated.

We start from the hypothesis that cultural schemas about work and family moderate individuals' reactions to job insecurity and the way in which this is related to family formation intentions. This hypothesis enables us to understand the persisting differences between eastern and western German timings of the transition to parenthood. In order to tackle this issue, we employ interpretative analyses of in-depth interviews with young adults in eastern and western Germany to investigate whether their perceptions of job insecurity and family formation are related to each other and in what ways. Germany represents an unprecedented opportunity to enhance our understanding of the relationship between job insecurity and fertility intentions. Forty years of separation shaped the labor market opportunities and demographic patterns of the postwar generations in very different ways prior to unification of the two regions . Looking at labor market opportunities in western Germany, from the 1950s to the early 1970s, the combination of a market economy with a conservative welfare regime (Esping-Andersen 1999) produced what has been termed "normal employment contractual conditions," characterized by the universality of permanent full-time contracts guaranteed by a strong social security system (Osterland 1990; Lutz 1984, 210 ff.). This situation traditionally favored the division of labor in the family, producing a highly gender-segregated labor market, with the majority of men employed in fixed full-time jobs and the majority of women experiencing labor-market exits or long interruptions after the transition to motherhood (Geissler 1998; Meyers et al. 1999; Sainsbury 1999). On the contrary, the socialist German Democratic Republic (GDR) provided virtually full and stable employment and expected men and women to participate equally in the labor market. Families were supported by a well-functioning and almost 


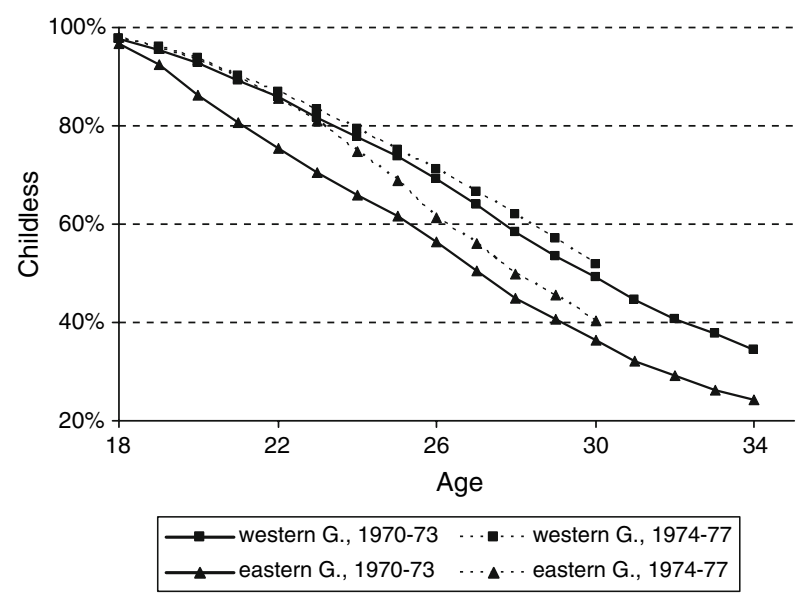

Fig. 1 Share of childless women by age and cohort. Cohorts 1970-1977 (Figure based on data from Kreyenfeld 2006)

universal system of health and childcare (Kohli 1994), ${ }^{2}$ and family enlargement was encouraged by the provision of housing and financial benefits for couples with children.

Employment opportunities changed gradually after the early 1970s in western Germany ${ }^{3}$ due to the increase in the numbers of temporary contracts and of job mobility, and they changed abruptly soon after reunification in eastern Germany through restructuring processes, privatizations, and unprecedented levels of unemployment. At the macro level, job instability became a permanent feature of the new federal states (Heinz 1996; Kurz et al. 2005), where changes in the institutional and socio-economic conditions were gradual, fertility also remained rather stable, but where the changes were rapid they were paralleled by correspondingly noticeable fertility dynamics. Despite the recent convergence in the quantum of fertility (Kreyenfeld 2003), significant divergences in the timing and forms of family formation persist and characterize the two regions. Figure 1 shows the divergent numbers of childless women from the cohorts 1970 to 1977 , observed in 2005. We see that the differences between eastern and western Germany still persist even for the younger cohorts. Whereas by the age of 28 already $50 \%$ of eastern German women from the youngest cohorts have had a first birth, it is only $38 \%$ of western Germans.

\footnotetext{
2 The 1961 Constitution of the GDR emphasized men's and women's duty of and right to paid employment, expressing a dual aspect: labor force participation was seen as a moral duty and as a precondition to participating in civil society and benefiting from public services (Frerich and Frey 1993).

${ }^{3}$ Postwar conditions faced major challenges from the 1970s on: The availability of apprenticeships became limited, the tendency to career interruptions and occupational changes grew, and a plurality of temporary and unstable employment forms emerged and rapidly multiplied, expressed in growing numbers of temporary contracts (Schreyer 2000; Puchert et al. 2005) and rising self-employment (MayerAhuja 2003; Bon $\beta$ 2002). These changes brought about feelings of uncertainty and of an economic decline in western Germany (Zapf 1996).
} 
In addition, eastern German mothers tend to stay in the labor market full-time and have preferences toward a gender-equal investment in their career and the family (Kreyenfeld 2004; Marbach and Tölke 2005). They still are younger than western German women when they have their first child, but it has been noted that the birth interval between the first and a second child is longer and second birth rates are lower (Kreyenfeld 2001).

Anticipating here our conclusion, we will show that differences in the demographic and institutional regimes have produced two different attitudes concerning the relationship between job insecurity and the timing of the transition to parenthood. In one context job security should come before parenthood, in the other context job security and parenthood are to be pursued in parallel. Where the latter attitude is dominant, job insecurity is likely to play a lesser role in fertility timing.

\section{Rationale: Job Instability and the Transition to Parenthood}

This section presents the current understanding of the relation between job instability and family formation as it is presented in the socio-demographic literature. We introduce the main assumptions and limitations in order to introduce the rationale behind our research design.

\subsection{Job Insecurity and Fertility: Two Demographic Narratives}

Global competition and an increasingly unpredictable economic environment have led to an increase in temporary labor force recruitment. By the same token, it has led to a general reduction in contract duration and to a growing need for labor mobility. The consequences of these changes are referred to in the literature as "precarious" working conditions (European Foundation 1998; Bourdieu 1998; Dörre 2005; Keller/Seifert 2006; Kraemer/Speidel 2005). These authors describe precariousness (job instability) as resulting in a widespread feeling of insecurity about careers (job insecurity), particularly for those workers with lower levels of employability. The related uncertainty about future prospects is likely to change the way in which people distribute and balance their investments between work and family spheres, and produce a delay in family formation or family enlargement.

There is substantial agreement in the socio-demographic literature that long-term commitments such as marriage and parenthood require some job stability or realistic future career prospects, and some immediate economic security (Oppenheimer 1988; McDonald 2000; Blossfeld et al. 2005). Economic, job, and residential insecurities related to job instabilities are seen to have an inevitable negative effect on fertility intentions and behavior (postponement or forgoing of fertility) because of the biographical uncertainty they entail (Kohler et al. 2002; Jackson 2002; Weston et al. 2004; Hobcraft 1996, p. 523; Chesnais 2000; Tölke and Diewald 2003; Tölke 2005; Kurz 2005). Two partially overlapping scientific "narratives" are used in demography to describe the consequences of job instability on fertility 
intentions and behavior. For simplicity, we will label them the "insecurity narrative," a narrative inspired by the theory of the new household economics of Becker (1981), and the "uncertainty" narrative, a narrative inspired by the sociopsychological uncertainty reduction theoretical framework from Friedman et al. (1994).

The insecurity narrative is well represented in the socio-demographic literature. Most demographic empirical studies on European populations that try to explain the relation between women's and men's careers and fertility use a home economics perspective as a starting point (e.g., Ranjan 1999, Kreyenfeld 2004; Köppen 2006; Vikat 2004). According to this perspective, a rational response to an uncertain labor market is to work longer and harder to obtain a fixed, full-time contract in order to reduce job insecurity (Mills and Blossfeld 2005, p. 19). Childbearing intentions are subordinate to the goal of achieving job and economic security through the investment in job stability, at least for one member of the couple. The main line of argument is that job instability equals economic insecurity because the former brings in its wake fluctuating incomes arising from unstable unemployment episodes and rapid job changes. In addition, job insecurity often requires high residential mobility (given the growing demand for flexibility and mobility). The notion of job and economic insecurity is related to expectations about one's own living standard and living style. Since parenthood is a resource-intensive and longterm commitment, it is likely to be postponed or forgone when income and working conditions are not perceived to be stable or continuous.

The uncertainty narrative identifies biographical uncertainty rather than economic insecurity per se as the major consequence of job instability. The "un-structuring of the life course" (Hurrelmann 2003), which is a consequence of the growing demands for flexibility in the educational and vocational spheres, brings forth increasing biographical uncertainty in terms of which choices are to be faced and in terms of their timing. According to this narrative, life course choices that reduce the level of uncertainty are particularly attractive. In this sense, parenthood is a way of producing biographical certainty (see among others Kohler and Kohler 2002, p. 255). Parenthood can thus be thought of as a force that works against the biographical uncertainty produced by precarious job situations-and can therefore be seen as something desirable.

The two narratives share some common ground. The first point of convergence is that both the insecurity and the uncertainty are deemed to be generally negative states that individuals will tend to avoid or reduce. In order to reduce or avoid them, individuals aim to make their future more predictable by increasing control over their circumstances (either by increasing investment in the working sphere or by entering the socially recognized status of parenthood). The second common aspect of the two narratives is that their supporters, with very few exceptions, base their empirical arguments on data that define both uncertainty and insecurity in relation to the socio-economic traits of individuals, rather than in relation to the subjective meaning individuals attach to them. The perspective that certainty and security are "intrinsic values" downplays the fact that individuals differ in the extent to which they perceive and tolerate insecurity and uncertainty (Weitz 1989; Heckhausen and Schulz 1995; Sverke and Hellgren 2002). 
These distinctions, however, are relevant since they have different consequences for family formation behavior, which in turn are central to understanding differentials in fertility intentions and behaviors in different contexts. Job instability may or may not produce job insecurity, and the consequence of job insecurity may or may not affect other life domains, such as family formation. Yet, most sociodemographic empirical literature relating job instability to fertility intentions or behavior is based on models that consider job insecurity as merely objective instabilities in the employment history, rather than subjectively defined insecurities and the ways in which they are related to other life domains (an exception is Johnson-Hanks 2004). This study provides an empirical basis to widen the range of theoretical narratives relating job instability and family formation.

\subsection{Job Insecurity and Fertility: Limits of the Current Empirical Literature}

Only a few population representative studies data look at the relationship in the German context between fertility and job insecurity, or the more objective indicator of job instability (Kurz et al. 2005; Bernhard and Kurz 2007; Kreyenfeld 2005; Vondracek 2000). Kurz et al. (2005) observe that job instability (defined as any labor market position other than having a permanent contract) does not have a negative impact on first birth for women, and only a partially negative impact on the transition to fatherhood. Their conclusion is that in Germany "it really matters whether a man is employed or not, but not what type of employment position he has" (Kurz et al. 2005, p. 77). Similar conclusions are reached for the birth of the second child: men who are employed with stable contracts are just as likely to have a second child as those with unstable contracts, whereas women with temporary contracts are less likely to become a mother for the second time if they are employed full-time (Bernhard and Kurz 2007). Unfortunately, these results do not allow the reader to draw conclusions on East-West differences within Germany.

In a study based on longitudinal data from western Germany, Kreyenfeld (2005) analyzes the role that the subjective perception of economic insecurity and general life satisfaction plays in first birth risks. She finds that the two factors have no linear effect on the transition to parenthood; it is only women with a relatively low level of education that have a higher risk of first birth, and they only decide to have children if they perceive their economic situation as insecure or not satisfactory. Conversely, a similar perception of economic insecurity amongst highly educated women leads to a reduced first birth risk.

Based on a correspondence analysis of two cross-sectional datasets collected respectively in an eastern and a western German city in 1991 and 1996, an explorative study by Vondracek (2000) complicates the picture by questioning whether the conflicting relation between high education and career investments and fertility predicted by economic models of fertility holds in both eastern and western Germany. The most relevant finding for our purpose is the trajectory of eastern German women who completed their academically oriented school paths in the year of unification (1990). A higher investment in education and a higher career orientation did not prevent eastern German women from having children 
earlier - this is contrary to the prediction of the economic model and to the attitudes of their vocationally oriented western German counterparts.

In sum, empirical evidence on the relationship between job instability and fertility between eastern and western Germany is incomplete and ambiguous. Moreover, the predicted slow but unequivocal convergence with the western model, once a unified socio-political framework was in place has not yet happened (Witte and Wagner 1995; Beck-Gernsheim 1997). One may ask whether the differences are based on some other reason than that of formal institutions and opportunity structures.

Sociology and lifespan psychology research address the importance of socialization in defining subjective orientations toward job and family. The baseline assumption of this literature is that the differences in the current behavior in re-unified Germany can be the result of past experiences with different economic, political, and labor market regimes. Due to socialization processes, the effects of these experiences continue to be observed in the generation who started their adult life after 1990. However, the results are ambiguous in this case, too.

On the one hand, in a study on eastern Germans' mentalities-defined as "internalized schemas of classification that originate from a specific societal context" (Alheit et al. 2004, p. 14) - the authors find that traditional everyday routines, behavioral patterns, and biographical perspectives have hardly changed with the new circumstances. Instead, they have been transferred from the older to the younger generation, and the latter just reproduces them in a sort of intergenerationally transmitted habitus (Alheit et al. 2004, 337 ff.; Alheit 2005, p. 33). The authors go as far as inferring an eastern German "resistance to modernization," a "barrier" to modernization, and a "backwardness" of mentalities from their qualitative study in a rural region of eastern Germany.

On the other hand, the assumption of a rigid mentality in eastern Germany is not consistent with other empirical analyses that focus on eastern German attitudes and behavioral changes after unification (Heckhausen 1994; Struck 2003; Diewald 2000). Heckhausen (1994) finds little difference between the life course and family orientation of western and eastern German adults living in Berlin in the early 1990s, with the exception of a stronger attachment to short-term life goals and a greater urgency in pursuing their immediate life goals among eastern Germans. Struck (2003) emphasizes the highly pragmatic and instrumentalist framing with which eastern Germans struggled to be included in the new postunification social structure despite having fewer resources. Along the same lines, Diewald (2000, 264 f.) states that occupational changes were considerably more frequent during the first three years of transformation than in western Germany or in Poland during the same period. According to the author, the occupational flexibility required of employees in the eastern region could and did draw on the considerable wealth of personal initiatives and occupational changes during GDR times.

All the above mentioned socio-demographic and socio-psychological studies point in one direction: despite the continuing convergence of the economic and institutional settings regulating the family and labor market policies, there are some persisting differences in attitudes, family formation behavior, and family orientations between the old and new federal states in Germany. The resilience of informal 
institutions, such as cultural norms and expectations related to job and family, may still distinguish the two regions and explain the differences in family formation patterns. If this is true, the social change affecting both eastern and western Germans may encounter nonuniform reactions. We address our data with the following research questions: Are unstable occupational careers a ground for job insecurity and economic insecurity? In what ways are job insecurity and economic insecurity related to prospects of family formation? Are there any differences, and if so, what type, in the way eastern and western Germans think of family and occupational careers, their relative priority, and their sequencing in a life course perspective?

\section{Sample, Data, and Methods}

We base our empirical analysis on the transcripts of semi-structured interviews with men and women living in two similarly sized northern German cities: Lübeck in the former Federal Republic of Germany, and Rostock in the former German Democratic Republic (respectively with a population of 215,000 and 198,000 inhabitants in 2002). We interviewed individuals born in about the year 1975 who attended the same school and graduated from either a Realschule in 1991 or from a Gymnasium in 1994. ${ }^{4}$ These are not population-representative samples of eastern and western Germany, of the two cities, nor of the schools themselves. However, choosing to select interviewees who were all former classmates from one school provided some control on unobserved early influences in adolescent years among subgroups of respondents, which is central to our argument on socialization. In addition, having comparable purposive samples (samples chosen according to the same criteria) in the two settings allowed us to focus on potential influences of socialization in different political, social, and family systems.

At the time of the interview, the respondents were about 30 years old; this is an age at which individuals enter a biographically dense stage in life, in which desires and aspirations related to job and family formation have to face reality and need to become more practical. The interview content and procedures are described at greater length elsewhere (see Bernardi et al. 2007). For the purposes of the current article it is important to remind the reader that we conducted a problem-centered semi-structured interview (Witzel 2000) containing narrative information on life course development since leaving school in 1994-in terms of education, employment, and family biographies and prospects-and life course priorities. This information was complemented by a network chart and network grid (Antonucci 1986; Straus 2002), and by a small socio-demographic and network questionnaire used to identify respondents' main characteristics and to map their social relational space.

In the following, we mainly employ the narrative parts of the interviews belonging to a sub-sample of our respondents (26), namely all those who in the

\footnotetext{
${ }^{4}$ A Realschule is a German secondary modern school with students graduating after the 10th grade, while a Gymnasium is equivalent to a high school, with students completing education after the 13th grade.
} 
original sample were living together with a partner and were childless at the time of the interview. Despite the fact that there may be some selectivity in excluding individuals who are not in a relationship due to some endogeneity of union, employment, and fertility processes, there are good reasons to limit ourselves to existing partnerships only. First, childbearing considerations are more salient and realistic when a partner is available and second, we can use the information related to two intertwined job histories (that of the respondent and of his/her partner). ${ }^{5} \mathrm{We}$ target childless couples because we want to focus on their current or prospective view on parenthood, before the experience of having already had a first child and the ex post facto rationalization that this event may bring with it. Respondents are equally distributed with respect to gender, educational background, and region of origin (eastern and western Germany). We chose respondents with secondary education or more because both in eastern and western Germany, it is the fertility behavior of the middle- and higher-educated which has changed most strongly in recent years, while that of the lower-educated has been relatively stable (Kreyenfeld 2001).

The sub-sample covers a large range of occupational careers and statuses, as well as perceptions of job security (see Table 1). The eastern-western difference in the socio-economic characteristics of the sub-sample members, such as lower educational attainment and less institutionalized partnerships in the Rostock sample, are consistent with the findings of population-representative studies of the regions, which reassure us that our sampling is not excessively distorted in these respects. The categorization of our respondents into low or high job insecurity was done according to interpretative criteria, and it deserves some words of explanation. We labeled as "low insecurity" respondents who (a) held a full-time, permanent employment position and had no concerns about losing their job in the near future; (b) held a temporary contract, but did not worry about a prolongation or their successive employability; (c) were still in education and either were already working with good prospects of keeping that job after finishing education or had a clear job perspective; and (d) were self-employed and have been running a successful business for several years. We labeled respondents as having a "high" job insecurity if they (a) held a full-time, permanent employment position and nevertheless worried about their future because of announced restructuring or downsizing processes; (b) held a temporary job contract and were worried whether it would be extended; (c) were still in education and had no clear future perspective or were worried about their employability; (d) were in the process of becoming selfemployed with very vague perspectives or highly risky plans. ${ }^{6}$

We used an interpretative thematic coding procedure (Glaser and Strauss 1967; Strauss and Corbin 1990; Flick 2002) to analyze the selected interviews. The creation of new codes and categories, and the examination of the narratives followed a recursive process in which new interviews are added during the analyses

\footnotetext{
5 We also interviewed the respondent's partner in all cases in which they were available and willing to participate. In these cases, we also have information on their perception of job security.

${ }^{6}$ In this category, we have two individuals in the eastern sample who-despite risky self-employment plans - are rather optimistic about their future. These risk-taking individuals show the weaknesses of using the concept of "job insecure" as an individual variable when attitudes toward risk are not controlled for.
} 


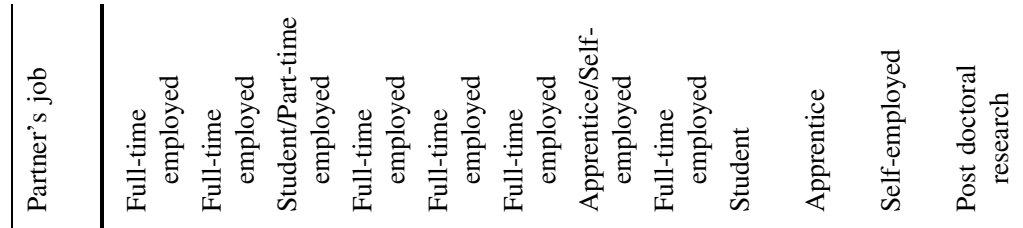

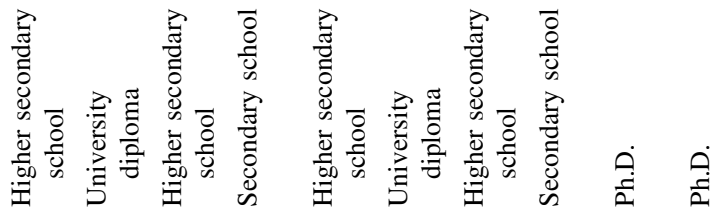

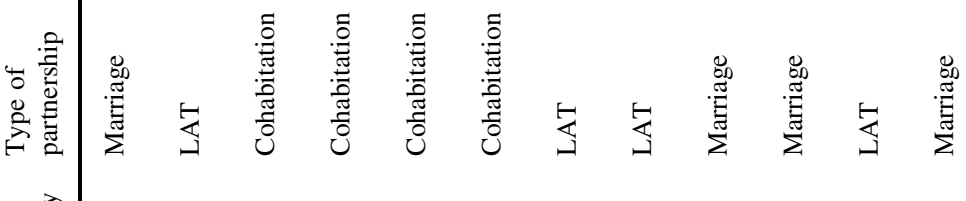

$$
\begin{aligned}
& \text { : } \\
& \text { 然. }
\end{aligned}
$$

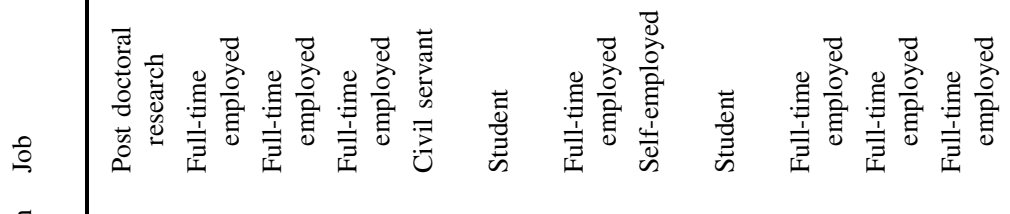

$$
\begin{aligned}
& \text { 产 }
\end{aligned}
$$

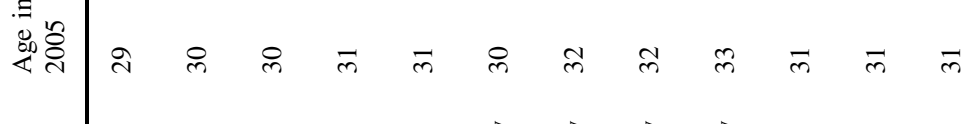

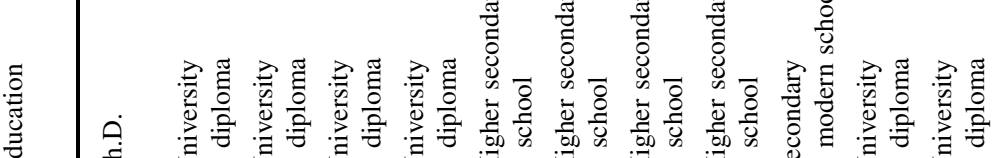

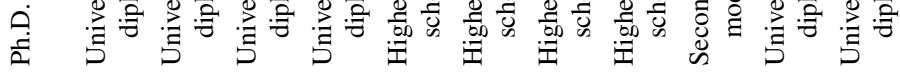

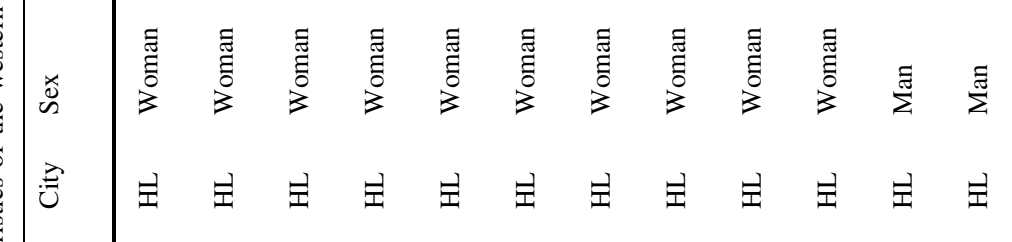

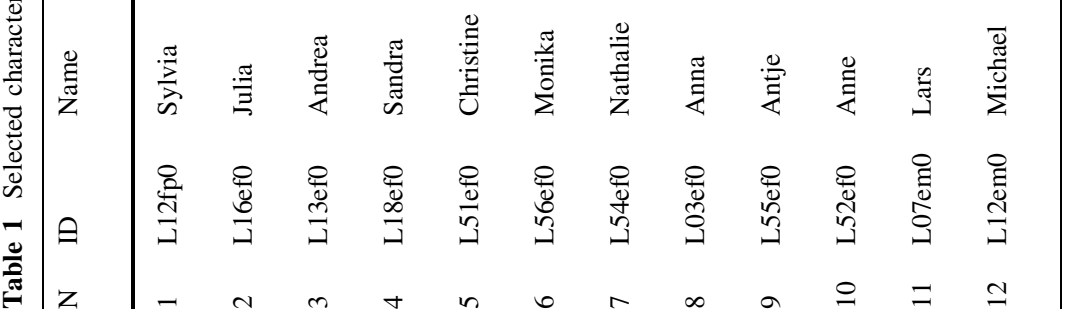




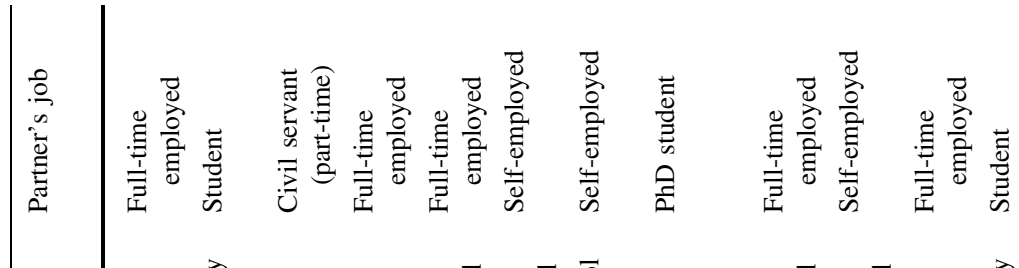

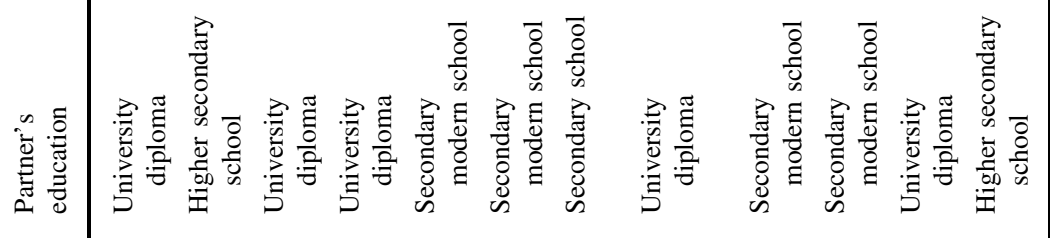

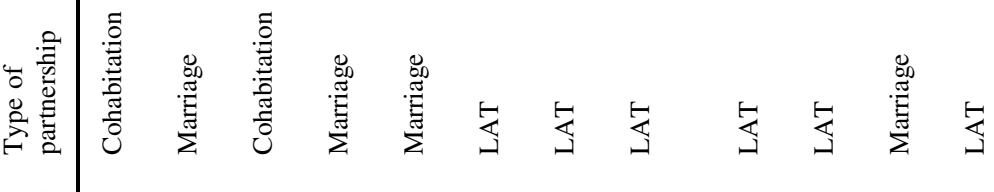

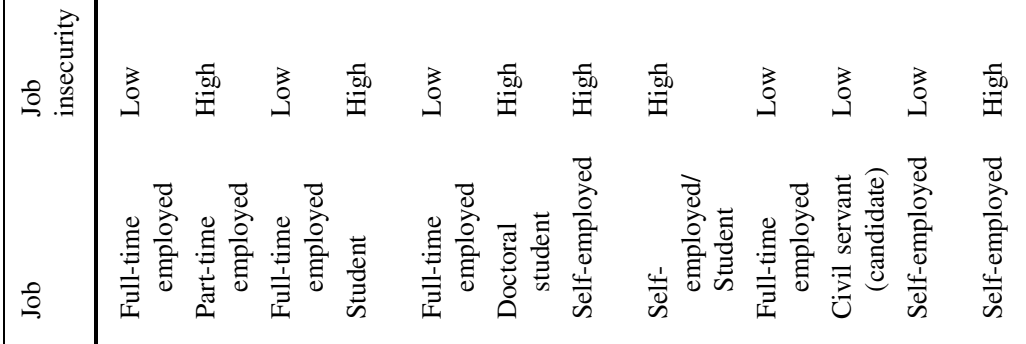

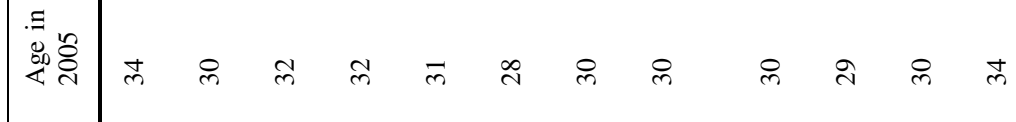

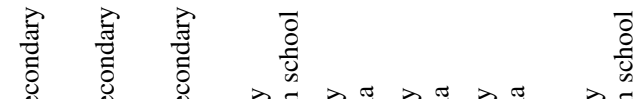

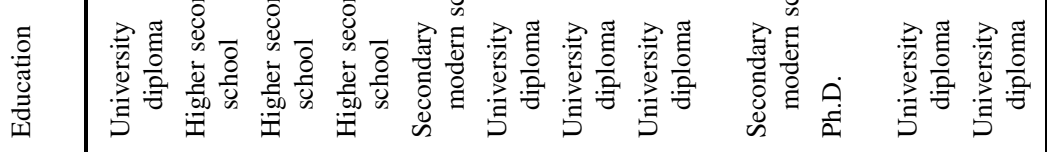

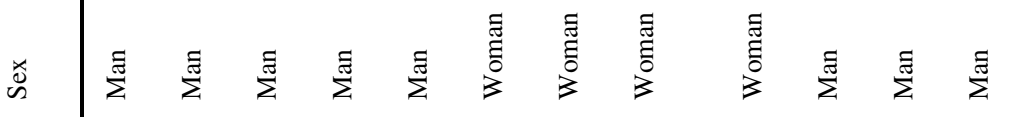

$$
\begin{aligned}
& \text { 导 }
\end{aligned}
$$

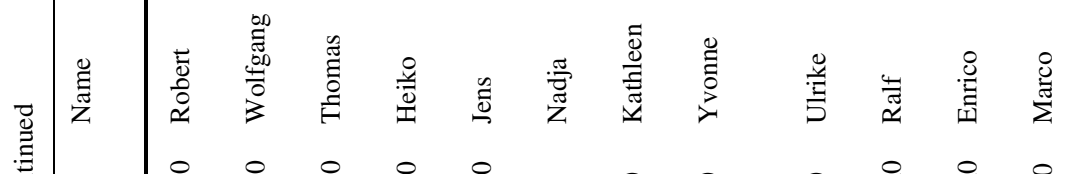

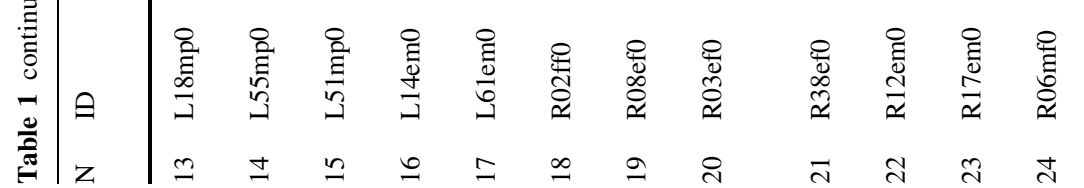




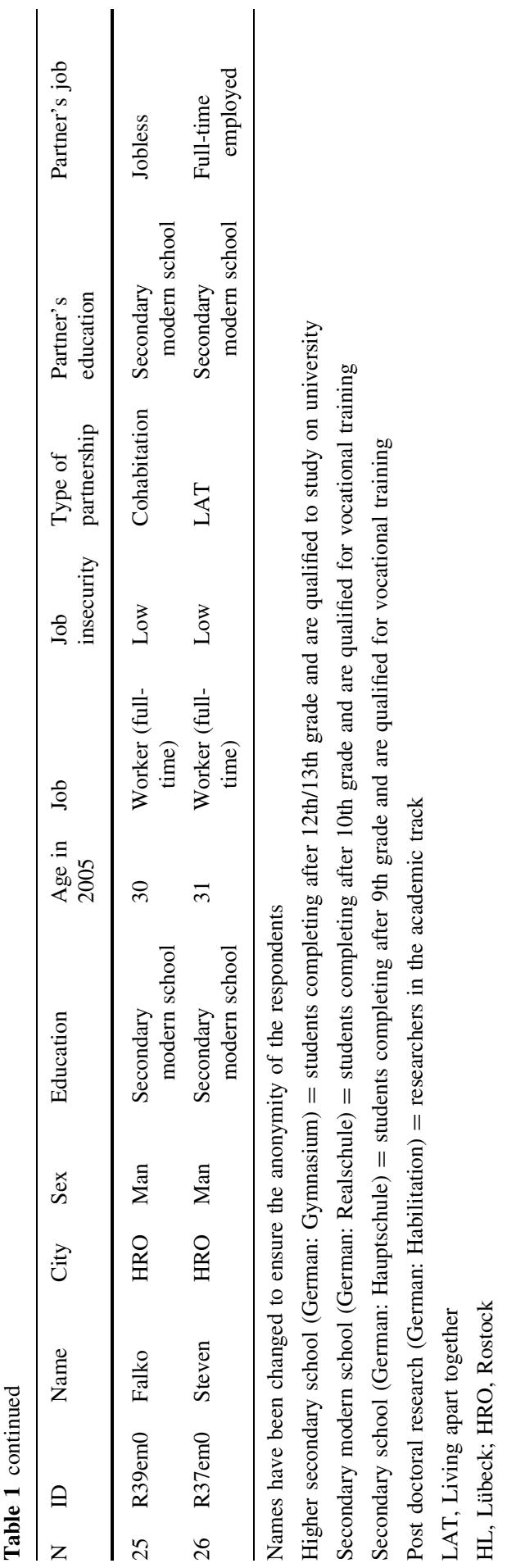


and contribute to the development of new categories or to their definition. From the coded text passages ("open coding"), the analyst develops a system of categories that encompasses the information of the codes in condensed form and allows for a comparison between groups ("selective coding"). These categories constitute the thematic structures of the interviews. In a two-step selective coding procedure, we first created a system of categories describing the meanings and attitudes related to employment and family formation abstracting codes from the individual cases. Then we identified typical patterns ("core categories") with which the previous categories could be related to each other. In the following section, we present the result of the comparative analysis of the categories developed with respect to the eastern and western German cases.

\section{Comparing Eastern and Western Narratives on Work and Family}

The outcomes of the last two steps of the analysis - the creation of the descriptive categories and the emerging patterns - are summarized in a schematic fashion in Table 2 and clarified in the following subsections. Finally, two case-illustrative studies bring life to the arguments advanced in the article, and show the internal consistency of two different ways of approaching job instability and family formation for our eastern and western respondents.

Table 2 Patterns and categories as they emerged from the sub-samples

\begin{tabular}{|c|c|c|}
\hline & Typical for the western sample & Typical for the eastern sample \\
\hline \multicolumn{3}{|c|}{$\underline{\text { Perceptions of jobs and occupational (in)stability }}$} \\
\hline Pattern name & Predictability & Balance \\
\hline \multirow[t]{3}{*}{ Categories } & Planning and a straight career path & $\begin{array}{l}\text { Correspondence of job, personal skills and } \\
\text { fields of interests }\end{array}$ \\
\hline & $\begin{array}{l}\text { Job stability equals economic } \\
\text { security }\end{array}$ & $\begin{array}{l}\text { Balance between job security, job } \\
\text { satisfaction and leisure time }\end{array}$ \\
\hline & An adequate and satisfactory job & $\begin{array}{l}\text { Attempts to limit personal strains caused by } \\
\text { job demands }\end{array}$ \\
\hline \multicolumn{3}{|c|}{ Frame of goals, aspirations, and priorities in life } \\
\hline \multirow{5}{*}{$\begin{array}{l}\text { Pattern name } \\
\text { Categories }\end{array}$} & Success & Diversity \\
\hline & Vocational success & An adequate job \\
\hline & Material property & Leisure time orientation \\
\hline & Spontaneity & Personal relations and commitments \\
\hline & Having a family and children & Having children \\
\hline \multicolumn{3}{|c|}{ Interrelatedness of job careers and family-formation } \\
\hline Pattern name & Sequencing & Parallelism \\
\hline \multirow[t]{3}{*}{ Categories } & $\begin{array}{l}\text { Stability is a prerequisite for } \\
\text { childbearing }\end{array}$ & $\begin{array}{l}\text { A balanced job situation is a prerequisite for } \\
\text { childbearing }\end{array}$ \\
\hline & Children are a potential threat & $\begin{array}{l}\text { Prospects of parenthood also determine job } \\
\text { choices }\end{array}$ \\
\hline & & Acceptance of parallel events \\
\hline
\end{tabular}




\subsection{Perceptions of Job and Occupational (In)Stability}

The overarching pattern among young western Germans' views and expectations about their jobs is that of predictability. This pattern emerges from three thematic categories related to their narratives on educational and employment careers: (1) The positive value associated with planning and a straight career path per se, (2) the interdependence of job stability and economic security, and (3) the specific definition of an adequate and satisfactory job.

The first category, planning and a straight career path, is related to respondents' reports of their investments in education and employment. Careful planning and a clear orientation to pursue advancement in the working life are key elements here. According to the western German respondents, a "straight career path" starts with a good education and leads to a successful and well-paid job. In order to achieve this goal, a considerable degree of personal distress and burden is accepted, such as commuting on a weekly or daily basis for a job with good career perspectives at the expense of time available for the partnership.

The second category concerns the definition of economic security and job stability as the main criterion to evaluate employment situations or career perspectives by western Germans. It partially overlaps with the first category, but it contains valuable characteristics of the job career beyond continuity. Stable job prospects, that is, working conditions that are virtually unaffected by contingent economic cycles or political crises, are the main features of a desirable job in western Germany. Examples given by respondents are related to holding a full-time permanent contract, possibly as a civil servant-a very stable and well-protected employment position in Germany-or to being employed in a branch in which positions are considered to be stable. In this sense, job stability equals economic security.

The third and last category is related to the perception of an adequate and satisfactory job situation in the western sample. Working life ideally should not be affected by difficult relations with colleagues, it should leave time and space for partnership, and where possible, it should not include commuting over weekends. However, these factors seem to be "soft factors" in the sense that they are hardly reasons to quit a job if it is a secure one. Interestingly, women are particularly concerned and worried about unclear perspectives related to their partner's job satisfaction. This is consistent with the fact that both men and women share the perception that it is mainly his job and his straight career path that counts, and that he has to provide a secure basis for family formation ("male breadwinner model").

A different view emerges from the narratives of the eastern German respondents. Here, the overarching pattern of young adults' conceptions of a desirable job is that of a sound balance between security and fulfillment. This pattern mirrors an attitude in which satisfaction derived from the job and its compatibility with other aspects of life is of equal or even higher value than job security and stability. Contrary to what the western respondents said, job interruptions, retraining episodes, and short-term contracts are perceived as good opportunities for personal development. The salient conceptions associated with educational and working careers are described by three thematic categories: (1) The correspondence of job, personal skills, and fields of 
interests, (2) attempts to limit personal strain caused by job demands, and (3) the balance of job security, job satisfaction, and leisure time.

The first category describes how job stability can be traded off for its positive appeal. Young adults from our Rostock sample consider it to be crucial for the evaluation of their education and employment choices that a job position fits with their personal interests and skills. According to their experience and views, they prefer to quit a job position if it does not match their personal interests. They would rather direct their efforts to the search for a more adequate position. This search often includes options of self-employment and freelancing in order to create a job that is placed in a less difficult job context.

Negative aspects of education and employment careers constitute the content of the second category, attempts to limit personal strain caused by job demands. Intense accounts of the emotional burden produced in times of loss of orientation or motivation are recurrent. Similarly, respondents often reflect on the difficulty produced by conflicting alternatives, involuntary breaks in education and job careers, strenuous migration histories, bad experiences with working-teams, or mobbing. Young eastern Germans view these as major problems in the labor force. Although these reports partially coincide with the difficulties reported by the western German sample, they are much more in the foreground in the eastern sample category and are rated as "hard factors" in judging one's job position.

The last category, balance of job security, job satisfaction, and leisure time, covers the main characteristic required of adequate employment conditions. For young eastern Germans, a desirable situation, a 'good job,' is a job that is neither overly strenuous nor unpleasant or unpredictable, and that provides enough money to live on ("some money"). The actual income and the career status clearly play a more marginal role than in western Germany. A sound "balance" between work and leisure time as well as between job demands and personal talents is more central here.

In sum, the system of categories describing young adults' views of job and biographical instability revealed major differences between eastern and western Germans. The categories show how central the concept of stability is to the western German respondents. The concept is associated with a predictable career path ending in stable employment or a secure perspective of continuous employment, and upward mobility at least for the male partner of a couple. Although some degree of predictability and stability is desired by the eastern respondents, too, the notion of employment security and a straight career path is not dominant, and balances out with the exploration and orientation aspects of turbulent and insecure education and employment careers.

\subsection{Framework of Goals, Aspirations, and Priorities in Life}

The analysis of the interviews concerning the question of the life goals, aspirations, and priorities shared by young adults revealed two more systems of categories. The western German sample is characterized by the centrality of success in the life course, whereas the eastern German sample produces a more heterogeneous system-a combination of various orientations. 
Having vocational success, that is, a successful job career, is a dominant orientation in the western German narratives on their life course in general. To our respondents, "success" means gaining a certain status, climbing up the career ladder, and earning "good money." Women set slightly different priorities and accord higher priority to the "fun" or the socializing aspects of their work. However, they put a strong emphasis on their male partners' career success and clearly expect their men to achieve it. This echoes the male-breadwinner model, which is evidently still persistent in western Germany.

Material property - embodied by owning a car or, more importantly, a flat or house-is a major priority in the life course of western Germans. Other priorities in life are, achieving a spontaneous lifestyle in social interaction and social life. A spontaneous lifestyle entails the desire for some degree of leisure-time planning (meeting friends, going out, etc.). Women add personal freedom and independence to their concept of self-realization. Additionally, family and children are a life course priority in the sense that they are perceived as valuable goals. Provided that a stable job leads to a stable partnership, having children is the natural step to take next.

Young adults from the eastern German sample also differ from their western counterparts as far as life course priorities are concerned. Notions of job stability and a good financial background are, albeit existing, less central to them. The idea of "life success through job career success" is missing. By contrast, they place a stronger emphasis on the value of leading a balanced life, which requires compromises to be made among different priorities to be pursued in parallel.

Finding an adequate job, i.e., a job that balances work with leisure time and with personal talents is an important aspect of the life course priorities of men and women in eastern Germany. The primary quality of an adequate job is not so much its stability, but rather that it leaves sufficient space to pursue personal interests, or that it truly reflects one's interests or talents (that is, the job is neither overburdening nor overly boring).

The next category, leisure-time orientation, contains all private priorities that are perceived as diametrically opposed to working life demands. These orientations at times lead people to refuse or terminate a job when it reduces the leisure time to an unacceptable minimum, or when the job hinders balanced self-realization in terms of hobbies, further education, or alternative interests. A strong emphasis in this context is put on personal relationships and commitments. They are expressed in the desire to spend time with one's friends and family, and feeling committed to other people or to one's hometown.

Finally, having children was an integral part of the life course for young eastern Germans. There was little understanding or appreciation for staying childless as a lifestyle choice. Reflections about the "best" point in time to become a parent entered the narratives only marginally, and they were superimposed by the preference for a rather spontaneous and "romantic" attitude toward having a child. "Too much planning" was seen and feared to be a cause of staying childless, and therefore it was not pursued. Contrary to the system of categories from the western sample, there was no evidence of an order or ranking within the system in the eastern sample. 


\subsection{Interrelatedness of Job Careers and Family Formation}

The categories presented in this section deal with the question of whether the perceptions of job instability and life course priorities are linked to the intentions of family formation in the western and eastern sub-samples and, if so, in what ways. Two distinct patterns emerge from the data: a sequential and a parallel pattern.

In the sequential pattern, i.e., the pattern prevalent in the western German sample, the prospects of parenthood are strongly related to the perceptions of job instability and biographical uncertainties. This pattern is summarized by two categorical perspectives: (1) the conception that stability in the vocational area, financial security, and a solid partnership are indispensable prerequisites to having children, and (2) the perception that children are a potential risk or threat to the personal lifestyle achieved.

In the western sub-sample, there were no considerations of having a family without having completed education first, being fully established in a job, or at least having clear job prospects. Respondents from western Germany do not regard the material and nonmaterial foundations of childrearing as being sufficient until a reliable situation of stability (economic security, stability of career, and partnership) has been achieved. However, the attitudes toward stability go even further: At times even a flourishing career can hinder childbearing if one partner (in particular the woman) is forced to accept residential mobility or daily/weekly commuting, since these are considered too strenuous to be compatible with childrearing. Women strongly express the trade-offs between childrearing and demanding full-time employment: a job and children are often seen as competing options. They feel either forced to abandon their career options in favor of having a child or to pursue the job career by postponing/giving up motherhood.

Accordingly, children are described as a risk to economic and biographical security. Young adults from western Germany are afraid that having children would endanger their attained living standard, and that their social status would suffer should they have children. Children also are seen as a threat to their desired spontaneous lifestyle and to self-realization because of the daily organizing and planning required to rear them responsibly.

In the parallel pattern, i.e., the pattern prevalent in the eastern German sample, job instability and the prospects of parenthood are interrelated in a less straightforward fashion. Here, the concepts of life course development and family formation are much less centered on the notion of stability and economic certainty, but instead the concept of balance and of the mutual reciprocity of two life spheres is emphasized. This pattern is summarized by three categorical perspectives: (1) the dependency of family formation on a balanced job situation for both partners, (2) prospects of parenthood also determine job choices, and (3) the relative downplaying of any interdependence between family plans and the claims of working life, i.e., the acceptance of parallel events in both fields.

In the eastern sample, the notion of the balanced job situation of both partners is as crucial in orienting family behavior as the notions of job and partnership stability in the western sample. A good balance is achieved when both partners participate in the labor force in one way or the other (dual-earner model), live in the same town, 
and have a moderate workload. By contrast, when the job situation is not balanced (that is, one partner is affected by work overload or there is only a single breadwinner), the prospects of becoming a parent diminish. There is little gender bias in the expression related to balance and imbalance-partners in Rostock seem to have exchangeable roles.

Typical of the eastern sample is that prospects of parenthood also determine job choices. For instance, most respondents refuse to meet demands for residential mobility in connection with labor force participation because they want to have a child, they choose professions compatible with future family plans, and they reduce their workload because of some incompatibilities with their partnership, or engage in retraining and change their job in order to meet the time demands of parenthood.

Contrary to what we learn from the western German narratives, in the eastern sample, job instability and parenthood perspectives are seen as two independent or mutually interacting aspects of life that are pursued in parallel ways: family formation during the start of a new job or during the transition to self-employment are typical instances of this attitude. The feeling that having children does not require any special preconditions except having an appropriate partnership ("balanced") because it is a natural part of life may lead the eastern German respondents to enter parenthood even in the absence of job security. In all narratives, there is an underlying discourse that indicates a less anxious approach to parenthood.

\subsection{Cultural Schemas at Work: Two Case Studies}

As the analysis of the cultural differences between eastern and western Germany suggests, individuals with similar socio-economic characteristics and comparable labor market perspectives may have very different intentions concerning family formation. Different interpretations of the life situation in terms of its economic and occupational security, a short-term versus a long-term perspective, and a sequential versus a parallel vision of the development of the various life domains like work and family, all contribute to shaping fertility intentions together with socio-economic characteristics. We briefly illustrate this point by presenting two typical cases, one from each region. By "typical," we mean a case which clearly embodies the analytical categories we developed from the analysis of the whole corpus of data. Lars from Lübeck (interview code L07em0) and Ralf from Rostock (interview code $\mathrm{R} 12 \mathrm{em} 0$ ) are both men in their early thirties, they hold a university degree, and their current life situations are to some extent comparable. They both describe themselves as being at the beginning of their job careers, are currently employed with timerestricted contracts, and they both wish to have stable full-time employment. They both live "apart together" with their partners, bridging the distance involved in their residential situation by commuting on a weekly basis. Their partners have a similar temporary job arrangements (in the sense that they wish to change them), either as part-time employees or as self-employed. Without being a proof in the strict sense of the word, their cases show the effect of cultural schemas on individuals' real-life decision-making processes. 
Lars (Lübeck): Although his employer is likely to renew his temporary contract, Lars is seeking a new job. The basis for his dissatisfaction with the current position is mainly related to the lack of a stable perspective and what he considers insufficient payment. He is actively seeking a new job "where you earn more and where you work on a non-temporary basis." Consistent with the dissatisfaction about his personal life, Lars repeatedly complains about the current economic condition in Germany as a whole, particularly because jobs become "more and more insecure, in most cases you have only temporary contracts." He describes his own situation as "dreadful," and this perception dominates his family formation intentions:

"... if I assume the worst case, the economy will break down, unemployment figures will rise to five million, I lose my job, my parents get jobless, then I don't think that I want to have children. I know many children of unemployed people and I want to spare my children this fate."

Although Lars and his partner would like to have children in general, he feels too insecure economically to seriously consider having them at the moment. His way of talking about prospective parenthood is very vague and resembles a future possibility rather than a concrete intention or plan:

"maybe in ten years, when I am 40 and secure in my professional life and when I am able to offer something to the child."

The need for security and stability for Lars is fundamental for both the economic and the socio-institutional spheres in his life. When considering the possibility that a pregnancy could "happen" without being planned, he would marry immediately because of the importance attributed to the marriage document:

"If one lives together so loosely, then everything is just so loose and slack..., I don't know... that's too insecure for me."

If, and only if, the two sources of security, economic and institutional stability, are achieved, then, in a strict sequencing of life course phases, he can consider the possibility of becoming a father.

Ralf (Rostock): Ralf, like Lars, sees himself in a transitional stage of his job career and aspires to a better position. However, when prompted with the perspective of that change, he expresses deep concerns about the fact that a new job may be too time-intensive, career-promoting, and absorbing, and he clearly wants to avoid such a strain. A job "has to be well-balanced (...) from the job and from the private perspective," he says. He often points toward the negative consequences of job success: "Your private life suffers from this [overstress due to job success] and, secondly, it is physically very tiring." Similarly, the commuting lifestyle he and his partner adopted is not satisfactory, though it has been necessary since she has her own business in another town. Since they want to have one or two children, she plans to sell her business soon and move in with him in order to start a family. He says: "Within the next one or two years [we will start a family], I guess." $\mathrm{He}$ expects his partner to start some sort of new business as soon as the child(ren) can go to day care. Likewise, Ralf also mentions the possibility that the first child may 
arrive earlier: "Perhaps this will also be a spontaneous thing." The spontaneity is related to the idea that Ralf and his partner feel emotionally ready to start a family, and they may not wait until all external conditions (job and money) are set to have their first child. Here the sequencing of events is much more flexible, while at the same time, the parallel development of career and family is also regarded as a reasonable alternative.

\section{Discussion: One Instability, Different Biographical Models}

The pivotal aim of this article was to understand whether job insecurity has consequences for family formation and whether these consequences vary according to the socio-cultural context. A general starting observation from our interview study is that all of the young adults experience job instability, either personally, or more often indirectly amongst acquaintances and friends, and/or as a perceived threat. However, the significance of job and economic security for the prospects of parenthood varies across the two regions of Germany.

While job security is crucial to the western Germans' idea of achievement and as a foundation for family formation in a sequential pattern, in eastern Germany, job security is only one of the parallel paths in one's life course and thus investments in one's job and private life are conducted in parallel. Our results show that western German couples tend to focus on and streamline their working career when faced with job instability and job insecurity. This recalls the well-known ideal of "the integrated life," which is "connected with a straight career path, [...] with a lack of discontinuity between the stages of the life cycle, and so on" (Riesman 1950, cited by Wohlrab-Sahr 1992, p. 218). This ideal is typically linked to the attitude of a rational, planned, and straightforward approach to life. It emerged as an ideal during the zenith of the "institutionalized life course" (Kohli 1985), which was characteristic of the 1960s and 1970s in western Germany. The foundation of this ideal was the life-long inclusion of the male breadwinner in the labor force, and this notion is echoed in the range of patterns and categories we find in the western subsample of young adults today. To refer back to the life course strategies discussed in Sect. 2.1, the western German respondents seem to apply the strategy of trying to increase predictability by a sequential approach. We suggest that the insecurity narrative can be convincingly used to interpret rising childlessness in western Germany.

We cannot reach the same conclusion for the eastern German respondents. Those who grew up in the former GDR handle the consequences of job instability in a more flexible way. Mainly, they pursue a "diversified portfolio" of priorities without strictly sequencing their achievements. The eastern respondents increase their chances to satisfy all of their life course priorities by accounting for the unpredictability of their achievements in terms of timing and sequencing of events. Instead of framing educational and occupational interruptions as defeats or accidents, they talk about them in terms of opportunities, allowing affective and rational inputs to guide behavior (Zinn 2004). In the literature on job insecurity, the appraisal of the situation by workers plays an important role, and it is well known 
that job instability and the feeling of job insecurity are not necessarily in a one-toone relation (van Vuuren et al. 1991). This alternative set of strategies, typically for the eastern German respondents, provides for an alternative narrative, what we may term the balancing narrative yet to be told by socio-demographers. The balancing narrative to interpret the relationship between job insecurity and fertility is characterized by a reduction in the expectation that the life course will be predictable at reasonable personal costs. Therefore, respondents who apply this narrative are very confident of being able to cope with job market hazards and with childbearing at the same time.

Our portrait of the way in which men and women with middle and high education from the graduation cohorts of 1991/1994 think of job insecurity and family formation in Rostock and Lübeck is based on a comparative sample, on rich narrative information, and systematic coding procedure. Our findings suggest an empirically grounded interpretation of the nonconvergence of eastern and western patterns of family formation. We have shown that the exposure to uncertain job careers leads to a different individual responses.. The difference between the sequential and the parallel life course careers of employment and family, or between a predictability strategy and a balancing strategy, is consistent both with the observed earlier transition to first birth in eastern Germany and with the rising childlessness and the faster transition to second births in western Germany. On the one hand, once western Germans decide to become parents, they probably have settled most issues related to their working life in the best way available to them and have overcome the feeling that their lifestyle may be threatened by children. With the exception of health and other biological limits, there are no other unpredictable obstacles to having a second or third child, provided it is desired. The question, though, is whether or not they succeed in starting with family formation at all, given the emphasis on strict sequencing and high achievement. On the other hand, in the eastern German sample, the more flexible attitudes to the timing of parenthoodattitudes that encourage first birth-may be a factor that delays successive childbearing because the desired balance between family and employment has to be reestablished and reevaluated before every successive childbearing decision.

Since our findings are based on two purposive samples, we refrain from extrapolating them to different cohorts, social strata, and regions; however, they do represent a piece of evidence which illustrate cultural and social mechanisms useful for interpreting regional differences in fertility behavior in these contexts, and we argue that these mechanisms should be subject to further testing with population representative samples and included in the theoretical accounts of behavioral differences within the reunified Germany.

We believe that our findings can be interpreted as the results of socialization into different social and political contexts. During the socialist regime, individual efforts to pursue a successful job career were meaningless because admission to higher education was granted by the state authorities, who also controlled career paths. In socialist times, eastern Germans used to withdraw into the private and personal niche of close friends and relatives to search for social and personal support instead of seeking success in the vocational sphere. The low interdependence between job stability and biographical uncertainty seems to be consistent with the attitude of 
considering demands from the public sphere (e.g., the labor force) less significant than relationships and commitments related to the private sphere.

The extent to which the distinctive orientations in the two German contexts depend on the harder economic and employment condition in eastern Germany is still an open question. On the one hand, one could expect that individuals would double their efforts in trying to achieve economic security when the chances of achieving it are lower. Assuming this rationale, our eastern respondents' intentions and behavior concerning family formation do not seem reasonable. On the other hand, one should remark that western Germans make their investments in some sort of job stability-postponing or forgoing childbearing as they do so-with a greater expectation that these investments are likely to pay off. In comparison, chances of success are less realistic, as in the East, and not proportional to individual efforts in the east. In the latter context, a parallel investment in family formation and job career may offer the better chances for positive pay-offs and therefore be fully reasonable.

The observed differences in discourse and strategies (predictability/balancing) seem to mirror the socialization of our eastern respondents in a system where not only the duty but also the right to family and work were unquestioned. The crucial difference between eastern and western Germans in our sample is constituted by the differential evaluation of life course priorities. While in the western German sample work orientations dominating, with the result that aims in the private sphere are postponed, in the eastern German sample a balance between work and private life is desired and actively pursued from the very early stages of the working career. Our findings and interpretation suggest provocatively that eastern Germans are enacting a new reactive model to job instability This model seems to have some parallels with the type of resistance that has been labeled "resistance" as "exit option" (Hirschmann 1970), that is a conscious and often verbalized refusal by eastern Germans to give up their priorities related to self-realization in the private spherein this case through becoming parents. This would be an "exit" in relation to the model of rigid sequencing and structuring that the western strategy to cope with job instability would suggest. To be provocative, and far from supporting Alheit and colleagues quoted claim of a typically eastern German "resistance to modernization" (see Sect. 2.2), one could say that the eastern mode of living with uncertainty represents the emergence of a postmodern orientation.

It is another question, however, to know whether and for how long the differences in orientation are likely to continue into the following generations, assuming that their origin can be retraced to different socializations. This question deserves further empirical research with longitudinal representative population data which could test some of the hypotheses we have delineated. On the basis of our selected case studies, this would appear to be one of the most interesting comparative settings for analyzing the interrelations between family and working careers.

Acknowledgments We thank Gerda Neyer, Angelika Tölke, and Hans-Peter Kohler for reading earlier versions of this article and providing important advice and critique. We also thank two anonymous reviewers for valuable comments. We credit Susann Backer and Craig Meulen for the language editing. 
Finally, we wish to express our gratitude to the Max-Plank-Institute for Demographic Research for providing us with the means to complete the research this article is based on.

\section{References}

Adler, M. A. (1997). Social change and declines in marriage and fertility in Eastern Germany. Journal of Marriage and the Family, 59(1), 37-49.

Ahn, N., \& Mira, P. (2002). A note on the changing relationship between fertility and female employment rates in developed countries. Journal of Population Economics, 15(4), 667-682.

Alheit, P. (2005). Modernisierungsblockaden in Ostdeutschland?: 15 Jahre deutsche Einheit. Aus Politik und Zeitgeschichte, 40, 32-40.

Alheit, P., Bast-Haider, K., \& Drauschke, P. (2004). Die zögernde Ankunft im Westen. Biographien und Mentalitäten in Ostdeutschland. Frankfurt am Main/New York: Campus.

Anderson, C. J., \& Pontusson, J. (2007). Workers, worries and welfare states: Social protection and job insecurity in 15 OECD countries. European Journal of Political Research, 46(2), 211-235.

Antonucci, T. C. (1986). Measuring social support networks: Hierarchical mapping technique. Generations, 10, 10-12.

Barling, J., \& Kelloway, E. K. (1996). Job insecurity and health: The moderating role of workplace control. Stress Medicine, 12, 253-259.

Becker, G. (1981). A treatise on the family. Cambridge: Harvard University Press.

Becker, S. O., Bentolila, S., Fernandes, A., \& Ichino, A. (2005). Youth emancipation and perceived job insecurity of parents and children, IZA Discussion Paper No. 1836, http://ssrn.com/abstract=857124 [14.03.2007].

Beck-Gernsheim, E. (1997). Geburtenrückgang und Kinderwunsch - die Erfahrung in Ostdeutschland. Zeitschrift für Bevölkerungswissenschaft, 22(1), 59-71.

Bernardi, L., Keim, S., \& von der Lippe, H. (2007). Social influences on fertility: A comparative mixed methods study in Eastern and Western Germany. Journal of Mixed Methods Research, 1(1), $23-47$.

Bernhard, S., \& Kurz, K. (2007). Familie und Arbeitsmarkt. Eine Längsschnittstudie zum Einfluss beruflicher Unsicherheiten auf die Familienerweiterung. IAB Discussion Paper, No. 10/2007, http://doku.iab.de/discussionpapers/2007/dp1007.pdf [14.06.2007].

Blossfeld, H.-P. et al. (Eds.). (2005). Globalization, uncertainty and youth in society. London: Routledge.

Bonß, W. (2002). Erosion des Normalarbeitsverhältnisses, Tendenzen und Konsequenzen. In A. Rauscher (Ed.), Arbeitsgesellschaft im Umbruch. Ursachen, Tendenzen, Konsequenzen (pp. 69-86). Berlin: Duncker \& Humblot.

Bourdieu, P. (1998). Prekarität ist überall. In P. Bourdieu (Ed.), Gegenfeuer (pp. 96-102). Konstanz: UVK.

Chesnais, J.-C. (2000). Determinants of below replacement fertility. Population Bulletin of the United Nations, 1999(40/41), 126-136.

D’Andrade, R. G. (1997). Schemas and motivation. In R. G. D’Andrade \& C. Strauss (Eds.), Human motives and cultural models (pp. 23-44). Cambridge: Cambridge University Press.

Diewald, M. (2000). Continuities and breaks in occupational careers and subjective control: The case of the East German transformation. In R. Silbereisen \& J. Bynner (Eds.), The effect of adverse and challenging circumstances on life course trajectories in the New Germany and England (pp. 239267). London: McMillan.

Dörre, K. (2005). Prekarisierung contra Flexicurity. Unsichere Beschäftigungsverhältnisse als arbeitspolitische Herausforderung. In M. Kronauer \& G. Linne (Eds.), Flexicurity. Die Suche nach Sicherheit in der Flexibilität (pp. 53-71). Berlin: Edition Sigma.

Elman, C., \& O'Rand, A. M. (2002). Perceived job insecurity and entry into work-related education and training among adult workers. Social Science Research, 31(1), 49-76.

Engelhardt, H., Kögel, T., \& Prskawetz, A. (2004). Fertility and women's employment reconsidered: A macro-level time-series analysis in developed countries, 1960-2000. Population Studies, 58, $109-120$.

Engelhardt, H., \& Prskawetz, A. (2004). On the changing correlation between fertility and female employment over space and time. European Journal of Population, 20, 35-62.

Esping-Andersen, G. (1999). The social foundations of postindustrial economies. Oxford: Oxford University Press. 
European Foundation for the Improvement of Living and Working Conditions. (1998). Precarious employment and working conditions in Europe. Luxembourg: Office for Official Publications of the European Communities, http://www.eurofound.europa.eu/pubdocs/1998/15/en/1/ef9815en.pdf [17.03.2007].

Flick, U. (2002). An introduction to qualitative research. Thousand Oaks: Sage.

Frerich, J., \& Frey, M. (1993). Handbuch der Geschichte der Sozialpolitik in Deutschland. Band 2: Sozialpolitik in der Deutschen Demokratischen Republik. München: Oldenbourg Verlag.

Friedman, D., Hechter, M., \& Kanazawa, S. (1994). A theory of the value of children. Demography, 31, 375-104.

Geissler, B. (1998). Weibliche Lebensführung und Erwerbsverlauf - Ein lebenslauftheoretischer Beitrag zur Analyse von Frauenarbeit. In B. Geissler, F. Maier, \& B. Pfau-Effinger (Eds.), FrauenArbeitsMarkt. Der Beitrag der Frauenforschung zur sozio-ökonomischen Theorieentwicklung (pp. 145164). Berlin: Sigma.

Glaser, B. G., \& Strauss, A. L. (1967). The discovery of grounded theory. Strategies for qualitative research. New York: De Gruyter.

Green, F. (2003). The rise and decline of job insecurity. Studies in Economics 0305, Department of Economics, University of Kent, http://ideas.repec.org/p/ukc/ukcedp/0305.html [14.03.2007].

Green, F. (2007). Job insecurity and wages. The Economic Journal, 117(518), 544-566.

Hartley, J., Jacobson, D., Klandermans, B., \& van Vuuren, T. (1991). Job insecurity: Coping with jobs at risk. London: Sage.

Heckhausen, J. (1994). Entwicklungsziele und Kontrollüberzeugungen Ost- und Westberliner Erwachsener. In G. Trommsdorff (Ed.), Psychosoziale Aspekte des sozialpolitischen Wandels in Ostdeutschland (pp. 124-133). Berlin: Walter de Gruyter.

Heckhausen, J., \& Schulz, R. (1995). Optimization by selection and compensation: Balancing primary and secondary control in life span development. International Journal of Behavioral Development, 16, 287-303.

Heinz, W. R. (1996). Transitions in youth in cross-cultural perspective: School-to-work in Germany. In B. Galaway \& J. Hudson (Eds.), Youth in transition to adulthood: Research and policy implications (pp. 2-13). Toronto: Thompson Educational Publishing.

Hirschman, A. O. (1970). Exit, voice, and loyalty: Responses to decline in firms, organizations, and states. Cambridge: Harvard University Press.

Hobcraft, J. (1996). Fertility in England and Wales: A fifty year perspective. Population Studies, 50(3), 485-524.

Hui, H. C. (1990). Work attitudes, leadership styles, and managerial behaviors in different cultures. In R. W. Brislin (Ed.), Applied cross-cultural psychology (pp. 186-208). Thousand Oaks: Sage Publications.

Hurrelmann, K. (2003). Der entstrukturierte Lebenslauf. Die Auswirkungen der Expansion der Jugendphase. Zeitschrift für Soziologie der Erziehung und Sozialisation, 23(2), 115-126.

Jackson, N. (2002). The higher education contribution scheme: A HECS on the family. Journal of Population and Research and New Zealand Population Review, Special issue, September, 105-120.

Johnson-Hanks, J. (2004). Uncertainty and the second space: Modern birth timing and the dilemma of education. European Journal of Population, 20, 351-373.

Kausto, J., Elo, A.-L., Lipponen, J., \& Elovainio, M. (2005). Moderating effects of job insecurity in the relationships between procedural justice and employee well-being: Gender differences. European Journal of Work and Organizational Psychology, 14(4), 431-452.

Keller, B., \& Seifert, H. (2006). Atypische Beschäftigungsverhältnisse: Flexibilität, soziale Sicherheit und Prekarität. WSI Mitteilungen, 5/2006, 235-240.

Klandermans, B., \& van Vuuren, T. (1999). Job insecurity: Introduction. European Journal of Work and Organizational Psychology, 8(2), 145-153.

Köppen, K. (2006). Second births in Western Germany and France. Demographic Research, 14(14), 295-330.

Kohler, H.-P., Billari, F. C., \& Ortega, J. A. (2002). The emergence of lowest-low fertility in Europe During the 1990s. Population and Development Review, 28(4), 641-680.

Kohler, H.-P., \& Kohler, I. (2002). Fertility decline in Russia in the Early and Mid 1990s: The role of economic uncertainty and labour market crises. European Journal of Population, 18, 233-262.

Kohli, M. (1985). Die Institutionalisierung des Lebenslaufs: Historische Befunde und theoretische Argumente. Kölner Zeitschrift für Soziologie und Sozialpsychologie, 37, 1-29. 
Kohli, M. (1994). Institutionalisierung und Individualisierung der Erwerbsbiographie. In U. Beck \& E. Beck-Gernsheim (Eds.), Riskante Freiheiten (pp. 219-244). Frankfurt/Main: Suhrkamp.

Konietzka, D., \& Kreyenfeld, M. (2004). Angleichung oder Verfestigung von Differenzen? Geburtenentwicklung und Familienformen in Ost- und Westdeutschland. Berliner Debatte Initial, 15(4), 26-41.

Kraemer, K., \& Speidel, F. (2005). Prekarisierung von Erwerbsarbeit. Zum Wandel eines arbeitsweltlichen Integrationsmodus. In W. Heitmeyer \& P. Imbusch (Eds.), Integrationspotenziale einer modernen Gesellschaft. Analysen zu Gesellschaftlicher Integration und Desintegration (pp. 367390). Wiesbaden: VS-Verlag.

Kreyenfeld, M. (2001). Employment and fertility: East Germany in the 1990s. Dissertation. Rostock: University of Rostock.

Kreyenfeld, M. (2003). Crisis or adaptation reconsidered: A comparison of East and West German fertility in the first six years after the 'Wende'. European Journal of Population, 19(3), 303-329.

Kreyenfeld, M. (2004). Fertility decisions in the FRG and GDR: An analysis with data from the German fertility and family survey. Demographic Research, S3(11), 276-318.

Kreyenfeld, M. (2005). Economic uncertainty and fertility postponement. Evidence from German panel data. MPIDR working papers, WP 2005-034, Max Planck institute for demographic research, Rostock, http://www.demogr.mpg.de/papers/working/wp-2005-034.pdf [14.03.2007].

Kreyenfeld, M. (2006). Der Einfluss der 'Wende' auf bildungsspezifische Fertilitätsunterschiede in Ostdeutschland. MPIDR Working Papers WP-2006-025, Max Planck Institute for Demographic Research, Rostock, http://www.demogr.mpg.de/papers/working/wp-2006-025.pdf [14.03.2007].

Kurz, K. (2005). Beschäftigungsunsicherheiten und langfristige Bindungen. Analysen zu Partnerschaftsverhalten, Familiengründung und zum Erwerb von Wohneigenturm. Habilitationsschrift. Universität Bamberg.

Kurz, K., Steinhage, N., \& Golsch, K. (2005). Case study Germany. Global competition, uncertainty and the transition to adulthood. In: H.-P. Blossfeld, E. Klijzing, M. Mills, \& K. Kurz (Eds.), Globalization uncertainty and youth society (pp. 51-81). London: Routledge.

Lutz, B. (1984). Der kurze Traum immerwährender Prosperität-Eine Neuinterpretation der industriellkapitalistischen Entwicklung im Europa des 20. Jahrhunderts. Frankfurt/New York: Campus.

Marbach, J., \& Tölke, A. (2005). Männer und Familie: Lebensorientierung, Kinderwunsch und Wirklichkeit. Paper presented at the workshop „Ein Leben ohne Kinder“, October 6-7, Max-PlanckInstitut für demografische Forschung and Rostocker Zentrum zur Erforschung des Demografischen Wandels, Rostock.

Mayer-Ahuja, N. (2003). Wieder dienen lernen? Vom westdeutschen „Normalarbeitsverhältnis” zu prekärer Beschäftigung seit 1973. Berlin: Edition Sigma.

McDonald, P. (2000). Gender equity in theories of fertility transition. Population and Development Review, 26(3), 427-439.

Meyers, M. K., Gornick, J. C., \& Ross, K. E. (1999). Public childcare, parental leave, and employment. In: D. Sainsbury (Ed.), Gender and welfare state regimes (pp. 117-146). Oxford: Oxford University Press.

Mills, M., \& Blossfeld, H.-P. (2005). Increasing uncertainty and changes in the transition to adulthood in modern societies. In H.-P. Blossfeld et al. (Eds.), Globalization, uncertainty and youth in society (pp. 1-24). London: Routledge.

Oppenheimer, V. K. (1988). A theory of marriage timing. American Journal of Sociology, 94, 563-591.

Osterland, M. (1990). 'Normalbiographie' und 'Normalarbeitsverhältnis'. In: P. A. Berger \& S. Hradil (Eds.), Lebenslagen, Lebensläufe, Lebensstile (pp. 351-362). Göttingen.

Probst, T. M., \& Brubaker, T. L. (2001). The effects of job insecurity on employee safety outcomes: Cross-sectional and longitudinal explorations. Journal of Occupational Health Psychology, 6, 139159.

Probst, T. M., \& Lawler, J. (2006). Cultural values as moderators of employee reactions to job insecurity: The role of individualism and collectivism. Applied Psychology: An International Review, 55, 234-254.

Puchert R., Gärtner M., \& Höyng S. (Eds.). (2005). Work changes gender: Men and equality in the transition of labour forms. Opladen: Barbara Budrich.

Ranjan, P. (1999). Fertility behavior under income uncertainty. European Journal of Population, 15, $25-43$.

Riesman, D. (1950). The lonely crowd. A study of the changing American character. New Haven: Yale University Press. 
Sainsbury, D. (1999). Taxation, family responsibilities, and employment. In D. Sainsbury (Ed.), Gender and welfare state regimes (pp. 185-210). Oxford: Oxford University Press.

Schwartz, S. H. (1990). Individualism-collectivism: Critique and proposed refinements. Journal of CrossCultural Psychology, 21, 139-157.

Schreyer, F. (2000). 'Unsichere' Beschäftigung trifft vor allem die Niedrigqualifizierten, IAB-Kurzbericht 15, http://doku.iab.de/ibv/2000/ibv4900_5013.pdf [2.6.2006].

Sobotka, T. (2004). Postponement of childbearing and low fertility in Europe. Amsterdam: Dutch University Press.

Statistisches Bundesamt, time series (available at: http://www.statistik-bund.de).

Straus, F. (2002). Netzwerkanalysen: Gemeindepsychologische Perspektiven für Forschung und Praxis. Wiesbaden: Deutscher Universitätsverlag.

Strauss, A., \& Corbin, J. (1990). Basics of qualitative research: Grounded theory procedures and techniques. Newbury Park: Sage.

Struck, O. (2003). Trajectories of coping strategies in Eastern Germany. In R. Humprey, R. Miller, \& E. Zdravomislova (Eds.), Biographical research in Eastern Europe. Altered lives and broken biographies (pp. 211-224). Hampshire: Ashgate.

Sverke, M., \& Hellgren, J. (2002). The nature of job insecurity: Understanding employment uncertainty on the brink of a new millennium. Applied Psychology, 51(1), 23-42.

Sverke, M., Hellgren, J., \& Näswall, K. (2002). No security: A meta-analysis and review of job insecurity and its consequences. Journal of Occupational Health Psychology, 7, 242-264.

Sverke, M., Hellgren, J., \& Näswall, K. (2006). Job insecurity-a literature review. SALTSA Report. No.1:2006. Stockholm, Sweden: National Institute for Working Life.

Tölke, A. (2005). Die Bedeutung von Herkunftsfamilie, Berufsbiographie und Partnerschaften für den Übergang zur Ehe und Vaterschaft. In A. Tölke \& K. Hank (Eds.), Männer-Das vernachlässigte Geschlecht in der Familienforschung (pp. 98-126).

Tölke, A., \& Diewald, M. (2003). Insecurities in employment and occupational careers and their impact on the transition to fatherhood in Western Germany. Demographic Research, 9(3), 41-67.

van Vuuren, T., Klandermans, B., Jacobson, D., \& Hartley, J. (1991). 'Employees' reactions to job insecurity. In J. Hartley et al. (Eds.), Job insecurity: Coping with jobs at risk (pp. 79-103). London: Sage.

Vikat, A. (2004). Women's labor force attachment and childbearing in Finland. Demographic Research, S3(8), 177-212.

Vondracek, F. W. (2000). Meeting challenges in the New Germany, in England: New directions for theory and data collection. In R. K. Silbereisen \& J. Bynner (Eds.), Meeting challenges in the new Germany and in England (pp. 291-302). London: Macmillan.

Weitz, R. (1989). Uncertainty in the lives of persons with AIDS. Journal of Health and Social Behavior, 30(39), 270-281.

Weston, R., Qu, L., Parker, R., \& Alexander, M. (2004). 'It's not for lack of wanting kids...' A report on the fertility decision making project, Australian institute of family studies (Research report no.11 2004), http://www.aifs.gov.au/institute/pubs/resreport11/aifsreport11.pdf [14.03.2007].

Witte, J. C., \& Wagner, G. G. (1995). Declining fertility in East Germany after unification: A demographic response to socioeconomic change. Population and Development Review, 21(2), 387-397.

Witzel, A. (2000). The problem-centered interview. Forum Qualitative Social Research, 1(1), http://www.qualitative-research.net/fqs-texte/1-00/1-00witzel-e.htm [23.09.2004].

Wohlrab-Sahr, M. (1992). Institutionalisierung oder Individualisierung des Lebenslaufs? BIOS. Zeitschrift für Biographieforschung und Oral History, 5(1), 1-19.

Zapf, W. (1996). Zwei Geschwindigkeiten in Ost- and Westdeutschland. In M. Diewald \& K.-U. Meyer (Eds.), Zwischenbilanz der Wiedervereinigung (pp. 317-328). Opladen: Leske and Budrich.

Zinn, J. (2004). 'Biographical certainty' in reflexive modernity. Paper presented at the life history and biography network conference of the European society for research on the education of adults (ESREA), http://www.esrea.org/conferences/Esrea\%202004/ESREA-papers/zinn.pdf [21.3.2006]. 